\title{
Nitrogen Fertilization and Irrigation Frequency Affect Hydrangea Growth and Nutrient Uptake in Two Container Types
}

\author{
Tongyin Li ${ }^{1}$, Guihong Bi, Richard L. Harkess, and Geoffrey C. Denny \\ Department of Plant and Soil Sciences, Mississippi State University, \\ Mississippi State, MS 39762
}

\section{Carolyn Scagel}

U.S. Department of Agriculture, Agricultural Research Service, Horticultural Crops Research Laboratory, 3420 NW Orchard Avenue, Corvallis, OR 97330

Additional index words. nitrogen rate, water use, biocontainer

\begin{abstract}
Plant growth, water use, photosynthetic performance, and nitrogen (N) uptake of 'Merritt's Supreme' hydrangea (Hydrangea macrophylla) were investigated. Plants were fertilized with one of five $\mathrm{N}$ rates $\left(0,5,10,15\right.$, or 20 mм from $\left.\mathrm{NH}_{4} \mathrm{NO}_{3}\right)$, irrigated once or twice per day with the same total daily amount of water, and grown in either a paper biodegradable container or a traditional plastic container. Greater $\mathbf{N}$ rate generally increased plant growth index (PGI) in both plastic and biocontainers. Leaf and total plant dry weight (DW) increased with increasing $N$ rate from 0 to $20 \mathrm{~mm}$ and stem and root DW were greatest when fertilized with $15 \mathrm{~mm}$ and $20 \mathrm{~mm} \mathrm{~N}$. Plants fertilized with $20 \mathrm{~mm} \mathrm{~N}$ had the greatest leaf area and chlorophyll content in terms of SPAD reading. Container type had no influence on DW accumulation or leaf area. $N$ concentrations $(\%)$ in leaves, roots, and the entire plant increased with increasing $N$ rate. $N$ concentrations in roots and in the entire plant were lower in biocontainers compared with plastic containers. Greater $\mathbf{N}$ rate generally increased daily water use (DWU), and biocontainers had greater DWU than plastic containers. The $20 \mathrm{~mm} N$ rate resulted in the highest net photosynthetic rate measured on 11 Sept. and 22 Sept. (65 and 76 days after treatment). Net photosynthetic rate (measured on 8 Oct.) and stomatal conductance $\left(g_{S}\right)$ (measured on 27 Aug., 22 Sept., and 8 Oct.) were lower in biocontainers compared with plastic containers. Two irrigations per day resulted in higher substrate moisture at $5-\mathrm{cm}$ depth than one irrigation per day, and slightly increased PGI on 19 Aug. However, irrigation frequency did not affect photosynthetic rate, $g_{S}$, or $\mathbf{N}$ uptake of hydrangea plants except in stems. Considering the increased water use of hydrangea plants when grown in the paper biocontainer and lower plant photosynthesis and $N$ uptake, the tested paper biocontainer may not serve as a satisfactory sustainable alternative to traditional plastic containers.
\end{abstract}

Hydrangea is one of the most popular ornamental crops used for both florist and landscape purposes because of their showy blooms in various sizes and shapes (OrozcoObando et al., 2005). There are more than 80 species in the genus Hydrangea, mostly used as ornamental shrubs. Hydrangea macro-

Received for publication 21 Aug. 2018. Accepted for publication 26 Oct. 2018.

This work was supported by the Mississippi Agriculture and Forestry Experiment Station and the U.S. Department of Agriculture (USDA) National Institute of Food and Agriculture Hatch project MIS-249180.

We thank Oregon Hydrangea Company, Brookings, OR, and Natchez Trace Greenhouse, Kosciusko, MS, for plant material.

Mention of a trademark, proprietary product, or vendor does not constitute a guarantee or warranty of the product by Mississippi State University or the USDA and does not imply its approval to the exclusion of other products or vendors that also may be suitable.

${ }^{1}$ Corresponding author. E-mail: t1665@msstate.edu. phylla, also known as bigleaf or French hydrangea, is considered the most popular (Reed et al., 2008; van Gelderen and van Gelderen, 2004). With more than 1000 cultivars, $H$. macrophylla is one of the most widely cultivated hydrangea species in the United States (Dirr, 2004). H. macrophylla blooms can be white, pink, red, purple, or blue, depending on cultivar and aluminum availability in the growing substrate (Dirr, 2004, 1998). They are low maintenance, have few pest and disease problems, can tolerate shade, and adapt well to both alkaline and acid soils (van Gelderen and van Gelderen, 2004). In the United States, the value of all hydrangea plants sold as nursery stock was $\$ 91$ million in 2012. An additional $\$ 30$ million were sold as potted flowering plants for indoor or patio use (U.S. Department of Agriculture, 2014).

Floral initiation of H. macrophylla occurs during the previous growing season, with flowers produced the following year on previous year's wood (Sun et al., 2015; Zhou and
Hara, 1988). Sufficient $\mathrm{N}$ fertilization is needed for perennial plants to increase stored $\mathrm{N}$ in the fall. Stored $\mathrm{N}$ is remobilized in the spring to facilitate new growth (Millard, 1995; Sanchez et al., 1991; Tagliavini et al., 1999; Weinbaum et al., 1984). Increasing N fertilization rate was reported to increase total $\mathrm{N}$ content in H. macrophylla 'Berlin' (Bi and Scagel, 2008). Bi et al. (2008) reported both vegetative growth and flowering during forcing were influenced by plant $\mathrm{N}$ status in the production of florists' $\mathrm{H}$. macrophylla 'Merritt's Supreme'. High N fertigation rates $\left(210\right.$ and $\left.280 \mathrm{mg} \cdot \mathrm{L}^{-1}\right)$ increased plant $\mathrm{N}$ content and improved flowering performance, number of flowers, and flower size in 'Merritt's Supreme' (Bi et al., 2008); however, $\mathrm{N}$ leachate resulting from excessive $\mathrm{N}$ application can cause contamination of groundwater, which is not environmentally sustainable or cost efficient for growers. Concerns have been raised regarding $\mathrm{N}$ runoff from nursery production and possible environmental contamination (Yeager et al., 1993). An efficient fertilizer management program involves specific knowledge on the rate and application method of $\mathrm{N}$ fertilizer as well as the plant growth response to such fertilization practices.

Plant nutrient uptake is also affected by irrigation method (Scagel et al., 2011, 2012). Increased irrigation frequency was reported to increase $\mathrm{N}$ use efficiency and uptake of calcium $(\mathrm{Ca})$ and decrease uptake of phosphorus $(\mathrm{P})$, potassium $(\mathrm{K})$, boron $(\mathrm{B})$, and zinc $(\mathrm{Zn})$ in Rhododendron species (Scagel et al., 2011, 2012). When the same total amount of irrigation water was delivered through more than one irrigation event, it decreased leaching from containers and compensated for certain nutrient deficiencies (Scheiber et al., 2008; Silber et al., 2003; $\mathrm{Xu}$ et al., 2004). The effect of irrigation frequency on nutrient uptake was attributed to possible altered $\mathrm{N}$ availability in the substrate and to differences in plant biomass among treatments.

It is challenging for growers to determine water requirements of a specific species because it is not clear how much water is available for uptake in soilless substrates and how water status affects plant growth and nutrient uptake (O'Meara et al., 2014). Plant species vary in their ability to absorb water and nutrients as growing substrate dries out. O'Meara et al. (2014) assessed how decreasing substrate volumetric water content (VWC) influenced water uptake of $H$. macrophylla 'Fasan' (hydrangea) and Gardenia jasminoides 'Radicans' (gardenia). Water use by hydrangea started to decrease at a higher VWC $\left(0.28 \mathrm{~m}^{3} \cdot \mathrm{m}^{-3}\right)$ than gardenia $\left(0.20 \mathrm{~m}^{3} \cdot \mathrm{m}^{-3}\right)$ and water uptake ceased at $0.16 \mathrm{~m}^{3} \cdot \mathrm{m}^{-3}$ in hydrangea, suggesting that hydrangea was less adept at extracting water from a drying substrate than the gardenia (O'Meara et al., 2014). For hydrangea, a relatively higher water content in the growing substrate should be maintained to maximize plant growth and avoid water stress

Sustainable alternatives have been studied in recent years to reduce use of plastic 
containers in nursery and greenhouse production of a number of ornamental crops (Beeks and Evans, 2013; Evans et al., 2010; Koeser et al., 2013; Kuehny et al., 2011; Nambuthiri et al., 2015; Wang et al., 2015). Biodegradable containers, also known as biocontainers, are made from a variety of biodegradable materials, such as feather, fabric, rice hulls, and paper, thus introducing varying influence on plant growth and nutrient uptake. Many tested biocontainers are able to produce plants of similar quality to traditional plastic containers (Beeks and Evans, 2013; Koeser et al., 2013; Kuehny et al., 2011; Li et al., 2015). However, compared with plastic containers, some biocontainers require more frequent irrigations and increased amounts of irrigation water when they are made from porous hydrophilic materials, for instance paper, which has high evaporation loss through the container sidewall (Evans et al., 2010; Koeser et al., 2013; Wang et al., 2015). The increased water use in biodegradable containers, mostly considered to be an insignificant contribution to total production cost (Brumfield et al., 2015), has an unforeseen impact on water status and nutrient availability in the substrate and, therefore, plant growth and nutrient uptake.

The objectives of this study were as follows: 1) to investigate plant growth and nutrient uptake of 'Merritt's Supreme' hydrangea in response to $\mathrm{N}$ fertilization rate, irrigation frequency, and container type; and 2) investigate water use of hydrangea growing in black plastic containers compared with biodegradable containers made from recycled paper.

\section{Materials and Methods}

Plant culture and treatments. One hundred rooted liners of 'Merritt's Supreme' hydrangea were transplanted into two types of containers on 1 July 2014: a black plastic container (GL 400; top diameter $17.78 \mathrm{~cm}$, bottom diameter $18.10 \mathrm{~cm}$, volume $3.785 \mathrm{~L}$; Nursery Supplies ${ }^{\circledR}$ Inc., Chambersburg, PA), or a biodegradable container (also referred as biocontainer) made from a mix of recycled paper $(7 \times 7$ round; interior top diameter 18.7 $\mathrm{cm}$, bottom diameter $14.9 \mathrm{~cm}$, height 17.1 $\mathrm{cm}$, volume $3.90 \mathrm{~L}$; Western Pulp Products Co., Corvallis, OR). Hydrangea plants were maintained outdoors under a shade structure with $50 \%$ black shadecloth at the R.R. Foil Plant Science Research center of Mississippi State University (U.S. Department of Agriculture hardiness zone 8a; $33.4552^{\circ} \mathrm{N}$, $88.7944^{\circ} \mathrm{W}$ ). A substrate containing $\approx 60 \%$ composted pine bark, $30 \%$ sphagnum peatmoss, and $10 \%$ perlite by volume (MetroMix 852; Sun Gro Horticulture, Agawam, MA) was used as the growing substrate. Each hydrangea plant was fertilized with $250 \mathrm{~mL}$ $\mathrm{N}$-free fertilizer $\left(1.06 \mathrm{mg} \cdot \mathrm{mL}^{-1}\right.$; Cornell No. N Eq. 0-6-27; GreenCare Fertilizers, Kankakee, IL) (Table 1) twice weekly plus 0,5 , 10,15 , or $20 \mathrm{~mm} \mathrm{~N}$ from $\mathrm{NH}_{4} \mathrm{NO}_{3}$ from 8 July to 22 Sept. 2014. Plants were irrigated through drip irrigation either once per day at $0800 \mathrm{HR}$ or twice per day at 0800 and 1430 HR with the same total daily irrigation volume. Plants were irrigated to replace daily water loss plus $10 \%$ to $15 \%$ leaching. Water loss was determined gravimetrically, and irrigation volume was corrected according to water loss of plants fertilized with $20 \mathrm{~mm} \mathrm{~N}$ grown in both container types.

Growth measurements. Plant height and widths (width 1 , the widest point; width 2 , perpendicular width of width 1) of each plant were measured every 2 weeks. Plant growth index (PGI) was calculated as the average of the plant height and two widths. Leaf chlorophyll content was estimated by leaf SPAD reading. Leaf SPAD for an individual plant was measured from three fully expanded new leaves every 2 weeks using a chlorophyll meter (SPAD 502 Plus; Konica Minolta, Inc., Osaka, Japan). Three readings from the three selected leaves were averaged to represent leaf SPAD of a specific plant.

Photosynthetic measurements. Leaf net photosynthetic rate and $g_{\mathrm{S}}$ of hydrangea plants were measured between 1000 and $1300 \mathrm{HR}$ on 27 Aug., 11 Sept., 22 Sept., and 8 Oct. 2014 using a portable photosynthesis system (LI-6400XT; LI-COR Biosciences, Lincoln, NE). One of the first two pairs of fully expanded leaves, not shaded by other leaves, were selected for photosynthetic measurements on a specific plant (Currey and Lopez, 2015). The selected leaf was enclosed into a 2-cm ${ }^{2}$ leaf chamber with a fluorometer light source. Photosynthetically active radiation of $1000 \mu \mathrm{mol} \cdot \mathrm{m}^{-2} \cdot \mathrm{s}^{-1}$ and a reference $\mathrm{CO}_{2}$ concentration of $400 \mu \mathrm{mol} \cdot \mathrm{mol}^{-1}$ were maintained inside the leaf chamber during photosynthetic measurements. Block temperature inside the leaf chamber was maintained according to the atmosphere temperature on the measurement date.

Daily water use and substrate moisture. Daily water use was measured in plants irrigated once per day. Daily water use was determined using a gravimetric method by subtracting pot weight (plant included) $24 \mathrm{~h}$ after irrigation from pot weight at container capacity (approximately one-half hour after irrigation). Substrate moisture at 5-cm depth in each container was measured using a soil moisture sensor (WaterScout SM 100; Spectrum Technologies, Inc., Aurora, IL). The moisture sensor was connected to a soil sensor reader (FieldScout ${ }^{\circledR}$ 6466; Spectrum Technologies, Inc.) for instant substrate moisture readings. Substrate moisture was measured at the midpoint between the plant stem and container sidewall after the second weighing of the container, $24 \mathrm{~h}$ after the first irrigation following DWU measurement. Daily water use and substrate moisture were measured on four dates: 21 Aug., 9 Sept., 25 Sept., and 9 Oct. 2014.

Plant harvest. Each plant was destructively harvested on 27 Oct. 2014, 119 d after transplanting. Plant samples were cleaned free of any substrate with deionized water, and separated into leaf, stem, and root tissues. All leaves from one plant were passed through a leaf area meter (LI-3100C; LI-COR Biosciences) to measure the total leaf area of each plant. Roots
Table 1. Formula of the N-free fertilizer applied to Hydrangea macrophylla plants in solution.

\begin{tabular}{lcl}
\hline Fertilizer 0-6-27 & Percentage (\%) & \multicolumn{1}{c}{ Form } \\
\hline Phosphate $\left(\mathrm{P}_{2} \mathrm{O}_{5}\right)$ & 6.8 & $\mathrm{~K}_{3} \mathrm{PO}_{4}$ \\
Potash $\left(\mathrm{K}_{2} \mathrm{O}\right)$ & 27.1 & $\mathrm{KCl}$ \\
Magnesium $(\mathrm{Mg})$ & 4.7 & $\mathrm{MgSO}$ \\
Iron (Fe) & 0.134 & $\mathrm{Fe}_{4} \mathrm{EDDHA}$ \\
Manganese $(\mathrm{Mn})$ & 0.048 & $\mathrm{M}_{\mathrm{n}} \mathrm{SO}_{4}$ \\
Zinc $(\mathrm{Zn})$ & 0.005 & $\mathrm{Z}_{\mathrm{n}} \mathrm{SO}_{4}$ \\
Copper $(\mathrm{Cu})$ & 0.002 & $\mathrm{CuSO}_{4}$ \\
Boron (B) & 0.048 & $\mathrm{H}_{3} \mathrm{BO}_{3}$ \\
Molybdenum (Mo) & 0.001 & $\mathrm{Na}_{2} \mathrm{MoO}_{4}$ \\
\hline
\end{tabular}

${ }^{\mathrm{z}}$ The soluble nitrogen-free fertilizer was applied at a rate of $1.06 \mathrm{mg} \cdot \mathrm{mL}^{-1}$, manufactured by GreenCare Fertilizers, Kankakee, IL.

of three freshly harvested plants from each treatment combination were scanned (EPSON ${ }^{\circledR}$ Expression 10000XL; Epson America, Inc., Long Beach, CA) for an image. Root length and surface area were analyzed using root analysis software (WinRHIZO, Regent Instruments Inc., Québec, QC, Canada). All samples were oven dried at $60^{\circ} \mathrm{C}$. Dry weight of each sample was recorded. Total DW of a specific plant was calculated by summing the DW of leaf, stem, and root tissues.

Tissue nitrogen analyses. Each dry sample was ground to pass a 1-mm sieve (Wiley Mill; Thomas Scientific, Swedesboro, NJ) for nutrient analyses. The Kjeldahl method was used for determination of total $\mathrm{N}$ concentration (\%) using $0.1 \mathrm{~g}$ of dry tissue (Bremner, 1965). Nitrogen content $(\mathrm{mg})$ was calculated by multiplying DW of each sample with its $\mathrm{N}$ concentration. Total $\mathrm{N}$ content of each plant was calculated by summing $\mathrm{N}$ content in leaf, stem, and root tissues. Average N concentration of a plant was then determined by dividing total plant $\mathrm{N}$ content by total plant $\mathrm{DW}$.

Experimental design and data analyses. This study was set up as a factorial arrangement of treatments in a completely randomized design. The $\mathrm{N}$ rate (five rates), container type (two types), and irrigation frequency (two frequencies) were the three main experimental factors providing 20 treatment combinations with five single-plant replications in each treatment combination. Significance of any main effect or the interaction among factors were determined by analysis of variance (ANOVA) using the GLM procedure of SAS (Version 9.4; SAS Institute, Cary, NC). Daily water use and substrate moisture data on different dates were subject to repeated measures with measurement date as a factor. Where indicated by ANOVA, means were separated by Fisher's protected least significant difference test at $P<0.05$.

\section{Results}

Plant growth index. The influence of $\mathrm{N}$ rate on PGI varied between container type on most measuring dates (Fig. 1; PGI shown only for 19 Aug. and 27 Oct.). In each container type, PGI increased with increasing $\mathrm{N}$ rate from 0 to $15 \mathrm{~mm}$, with similar PGI between 15 and $20 \mathrm{~mm} \mathrm{~N}$ on 19 Aug. and 27 Oct. On 19 Aug., after $42 \mathrm{~d}$ of treatment, biocontainers resulted in $18.5 \%, 9.8 \%$, and $7.6 \%$ greater PGI than plastic containers at 
10,15 , and $20 \mathrm{~mm} \mathrm{~N}$, respectively. By the end of the experiment on 27 Oct., PGI was similar between container types at any $\mathrm{N}$ rate from 5 to $20 \mathrm{~mm}$. Irrigation frequency influenced PGI only at $42 \mathrm{~d}$ (19 Aug.) when two irrigations per day produced plants with $5.9 \%$ higher PGI than one irrigation per day (Fig. 1C).

Leaf SPAD. Relative leaf chlorophyll content (estimated via SPAD) was affected by $\mathrm{N}$ rate on all measurement dates (Fig. 2A; SPAD shown only for 27 Oct. at the end of the season). Plastic containers increased SPAD readings by $7.0 \%, 4.4 \%, 3.4 \%$, and $4.4 \%$ compared with biocontainers on 24 July, 21 Aug., 5 Sept., and 3 Oct., respectively (data not shown). Leaf SPAD was not influenced by irrigation frequency. On 27 Oct., plants fertilized with $20 \mathrm{~mm} \mathrm{~N}$ had the greatest SPAD readings. Leaf SPAD readings between plants fertilized with 5,10 , or $15 \mathrm{~mm}$ $\mathrm{N}$ were similar, all of which resulted in higher SPAD readings than the no $\mathrm{N}$ treatment.

Dry weight and leaf area. Greater $\mathrm{N}$ rate increased total plant DW and leaf DW from 0 to $20 \mathrm{~mm}$ (Fig. 3). Stem and root DW increased with increasing $\mathrm{N}$ rate from 0 to $15 \mathrm{~mm}$, with no difference between plants fertilized with 15 or $20 \mathrm{~mm} \mathrm{~N}$. Leaf area of hydrangea plants also increased with increasing $\mathrm{N}$ rate from 0 to $20 \mathrm{~mm} \mathrm{~N}$ (Fig. 2B). Container type and irrigation frequency had no influence on plant DW or leaf area.

Root length and surface area. The influence of $\mathrm{N}$ rate on total root length varied between container types (Fig. 4A). In general, 10 to $20 \mathrm{~mm} \mathrm{~N}$ resulted in the greatest root lengths and $0 \mathrm{~mm} \mathrm{~N}$ resulted in the least in both plastic and biocontainers. Biocontainers resulted in greater root length than plastic containers at $5 \mathrm{~mm}$ N. Root length peaked at $15 \mathrm{~mm} \mathrm{~N}$ in biocontainers and at $10 \mathrm{~mm} \mathrm{~N}$ in plastic containers, resulting in similar root length at $\mathrm{N}$ rates of 10 to $20 \mathrm{~mm}$ in biocontainers or plastic containers. Irrigation frequency altered the effect of $\mathrm{N}$ rate on total root length (Fig. 4B). Nitrogen rates of 15 and $20 \mathrm{~mm}$ resulted in greater root length than 0 or $5 \mathrm{~mm} \mathrm{~N}$ regardless of irrigation frequency. Irrigation frequency influenced root length only at 10 and $15 \mathrm{~mm} \mathrm{~N}$. More frequent irrigation increased root length at $10 \mathrm{~mm} \mathrm{~N}$ and had the opposite effect at $15 \mathrm{~mm}$ $\mathrm{N}$. Root surface area was affected by $\mathrm{N}$ rate, but not by container type or irrigation frequency (Fig. 4C). Root surface area increased with increasing $\mathrm{N}$ rate from 0 to $15 \mathrm{~mm}$ $\mathrm{N}$, with no difference between plants fertilized with 15 or $20 \mathrm{~mm} \mathrm{~N}$.

Daily water use and substrate moisture. Daily water use increased with $\mathrm{N}$ rate from 0 to $15 \mathrm{~mm} \mathrm{~N}$, with 15 and $20 \mathrm{~mm} \mathrm{~N}$ resulting in similar DWU (Fig. 5A). Greater DWU was consistent with increased PGI and dry weight of hydrangea plants using similar high $\mathrm{N}$ rates. Biocontainers resulted in $16.2 \%$ greater DWU than plastic containers (Fig. 5B). In general, substrate moisture decreased with increasing $\mathrm{N}$ rate, with no difference between 5 and $10 \mathrm{~mm} \mathrm{~N}$, or between 15 and $20 \mathrm{~mm} \mathrm{~N}$ (Fig. 6A). Nitrogen rates of $15 \mathrm{~mm}$ and $20 \mathrm{~mm}$

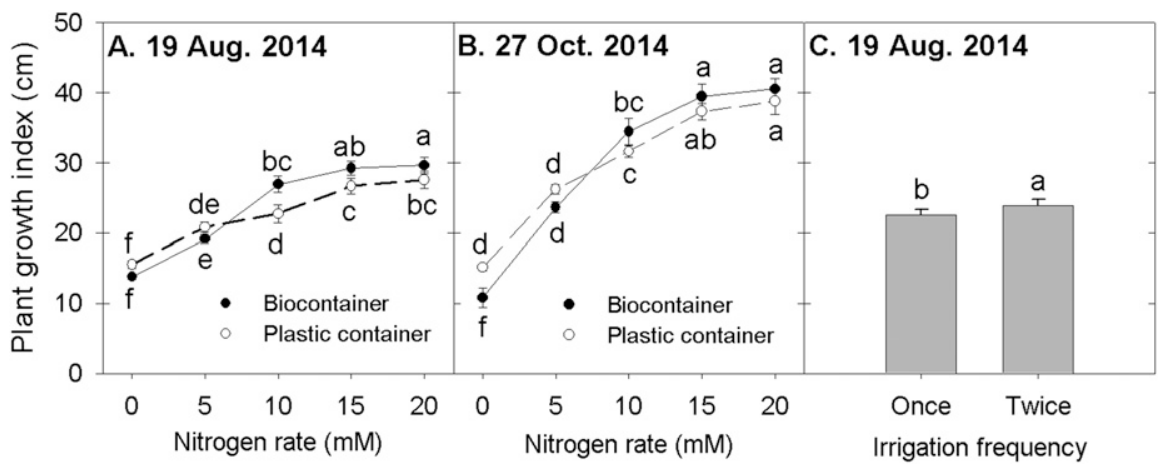

Fig. 1. Plant growth indices (PGIs) of Hydrangea macrophylla 'Merritt's Supreme' affected by the interaction between $\mathrm{N}$ rate and container type on 19 Aug. 2014 (A) and on 27 Oct. 2014 (B), or by irrigation frequency on 19 Aug. 2014 (C). Hydrangea plants were fertilized with $0,5,10,15$, or $20 \mathrm{~mm}$ $\mathrm{N}$ from $\mathrm{NH}_{4} \mathrm{NO}_{3}$, grown in plastic container or paper biocontainer, and irrigated once or twice per day with the same total daily irrigation volume. Plant growth index was calculated as the average of plant height, width 1 (widest points apart), and width 2 (perpendicular to width 1). Different lowercase letters in a figure suggest significant difference among all treatment combinations compared by Fisher's least significant difference test at $P<0.05$.
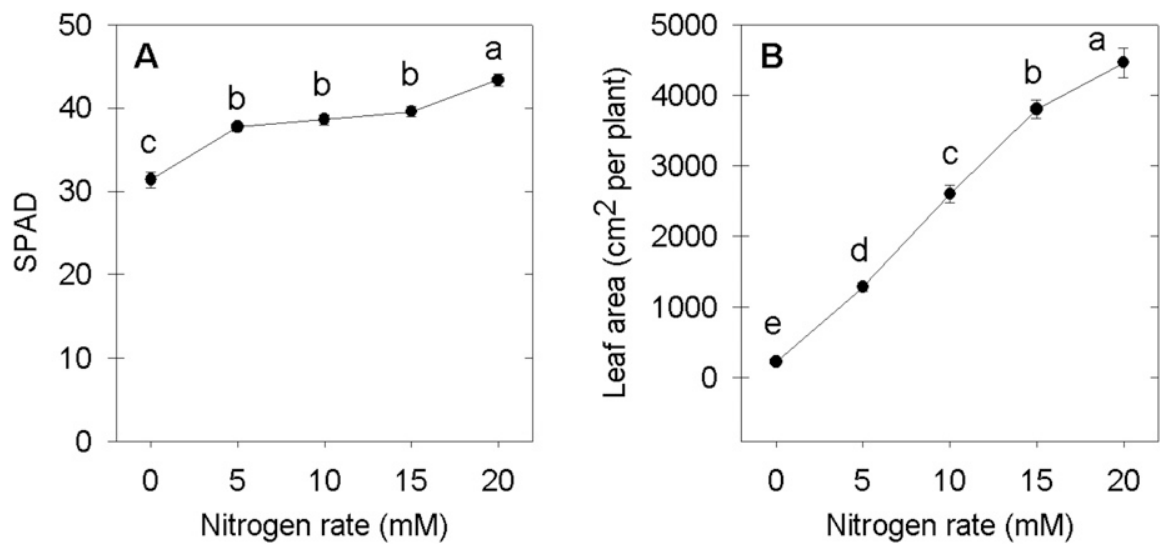

Fig. 2. Effect of $\mathrm{N}$ rate on leaf SPAD reading (A) and leaf area (B) of Hydrangea macrophylla 'Merritt's Supreme' on 27 Oct. Hydrangea plants were fertilized with $0,5,10,15$, or $20 \mathrm{~mm} \mathrm{~N}$ from $\mathrm{NH}_{4} \mathrm{NO}_{3}$. Irrigation frequency or container type did not affect SPAD or leaf area. Different lowercase letters in a figure suggest significant difference among $\mathrm{N}$ rate treatments compared by Fisher's least significant difference test at $P<0.05$.

resulted in the lowest substrate moisture. Plastic containers had $10.1 \%$ lower substrate moisture at $5-\mathrm{cm}$ depth than biocontainers (Fig. 6B). More frequent irrigation resulted in $13.2 \%$ greater substrate moisture before onset of scheduled irrigation in the morning (Fig. 6C).

Photosynthetic rate. The influence of $\mathrm{N}$ rate on net photosynthetic rate varied between container types on 27 Aug. (Fig. 7A). Plastic containers resulted the highest net photosynthetic rate on 27 Aug. at $\mathrm{N}$ rates of 10 to $20 \mathrm{~mm}$, higher than that of plants grown in biocontainers at similar $\mathrm{N}$ rates as well as those fertilized with 0 or $5 \mathrm{~mm} \mathrm{~N}$ grown in plastic or biocontainers. Nitrogen rate affected net photosynthetic rate measured on 11 Sept., 22 Sept., and 8 Oct. (Fig. 7B-D). On 11 Sept. and 22 Sept., N rate of $20 \mathrm{~mm}$ resulted in higher net photosynthetic rate than 0 and $5 \mathrm{~mm} \mathrm{~N}$, with no $\mathrm{N}$ resulting in the lowest net photosynthetic rate. On 8 Oct., net photosynthetic rates were generally higher when plants were fertilized with $\mathrm{N}$ than the no $\mathrm{N}$ treatment. In addition, on 8
Oct., there was a container effect on net photosynthetic rate where net photosynthetic rate was $10 \%$ greater in plastic containers than in biocontainers (Fig. 7E).

Irrigation frequency did not affect net photosynthetic rate of hydrangea plants in this study on any measurement date.

Stomatal conductance. The effects of $\mathrm{N}$ rate on $g_{\mathrm{S}}$ varied among the four measuring dates (Fig. 8). On 27 Aug., plants fertilized with $\mathrm{N}$ from 5 to $20 \mathrm{~mm}$ had similar $g_{\mathrm{S}}$, and $g_{\mathrm{S}}$ of N-fertilized plants was higher than those fertilized with no N. On September measurement dates, $g_{\mathrm{S}}$ generally increased with $\mathrm{N}$ rate (11 Sept.) or had little influence on $g_{\mathrm{S}}(22$ Sept.). At the end of the study, $\mathrm{N}$ rates from 0 to $10 \mathrm{~mm}$ resulted in higher $g_{\mathrm{S}}$ than the rates of 15 or $20 \mathrm{~mm} \mathrm{~N}$ on 8 Oct. Plants grown in plastic containers had greater $g_{\mathrm{S}}$ than plants in biocontainers on the three dates measured. Irrigation frequency did not influence $g_{\mathrm{S}}$.

Tissue $N$ concentration. Generally, increasing $\mathrm{N}$ rate resulted in increasing $\mathrm{N}$ concentration in leaf and root tissues, as well as the plant average, with $20 \mathrm{~mm} \mathrm{~N}$ producing 


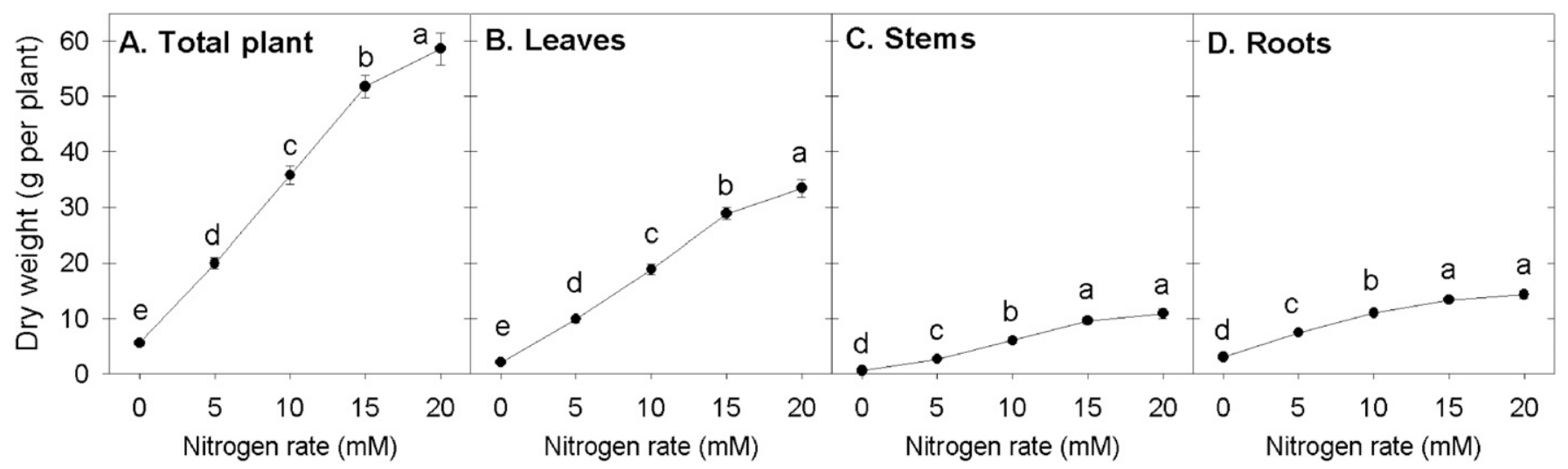

Fig. 3. Dry weights of Hydrangea macrophylla 'Merritt's Supreme' in the total plant (A), leaves (B), stems (C), and roots (D) affected by N rate. Hydrangea plants were fertilized with $0,5,10,15$, or $20 \mathrm{~mm} \mathrm{~N}$ from $\mathrm{NH}_{4} \mathrm{NO}_{3}$. Irrigation frequency or container type did not affect dry weights in leaves, stems, roots, or the entire plant. Different lowercase letters in a figure suggest significant difference among $\mathrm{N}$ rate treatments compared by Fisher's least significant difference test at $P<0.05$.
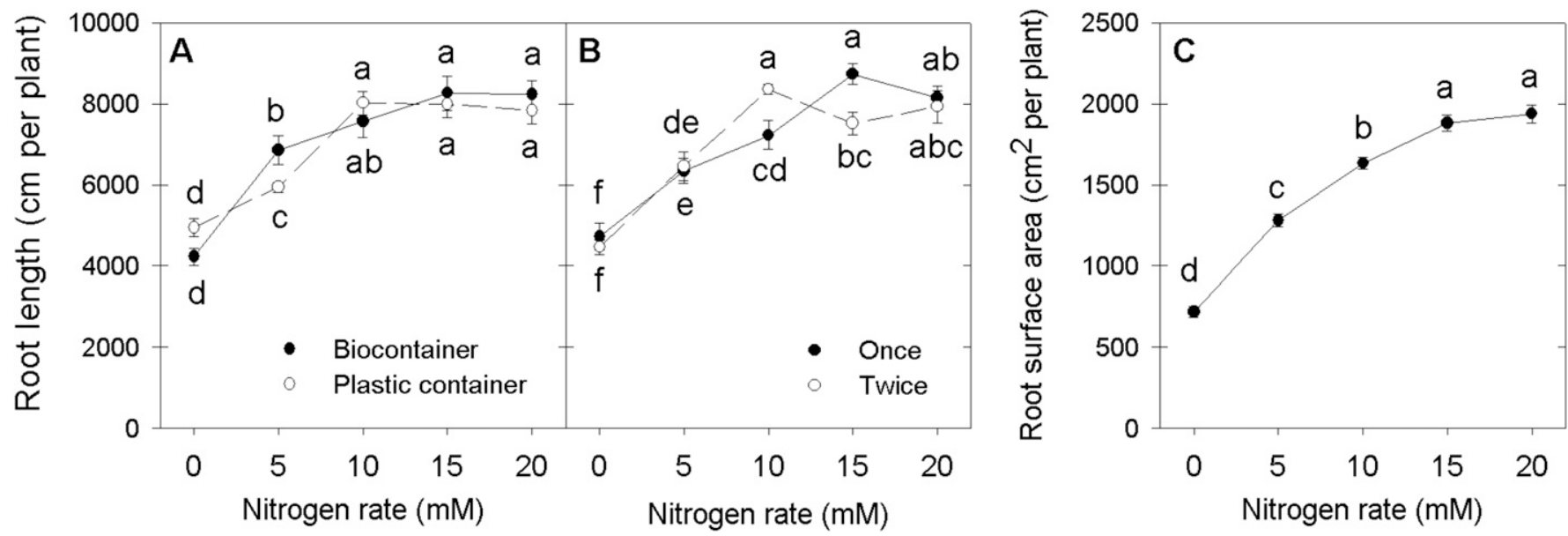

Fig. 4. Root length and surface area of Hydrangea macrophylla 'Merritt's Supreme' affected by the interaction between $\mathrm{N}$ rate and container type (A), by the interaction of $\mathrm{N}$ rate and irrigation frequency $(\mathbf{B})$, or by the main effect of $\mathrm{N}$ rate $(\mathbf{C})$. Hydrangea plants were fertilized with $0,5,10,15$, or $20 \mathrm{~mm} \mathrm{~N}$ from $\mathrm{NH}_{4} \mathrm{NO}_{3}$, grown in plastic container or paper biocontainer, and irrigated once or twice per day with the same total daily irrigation volume. Different lowercase letters in a figure suggest significant difference among all treatment combinations compared by Fisher's least significant difference test at $P<0.05$.

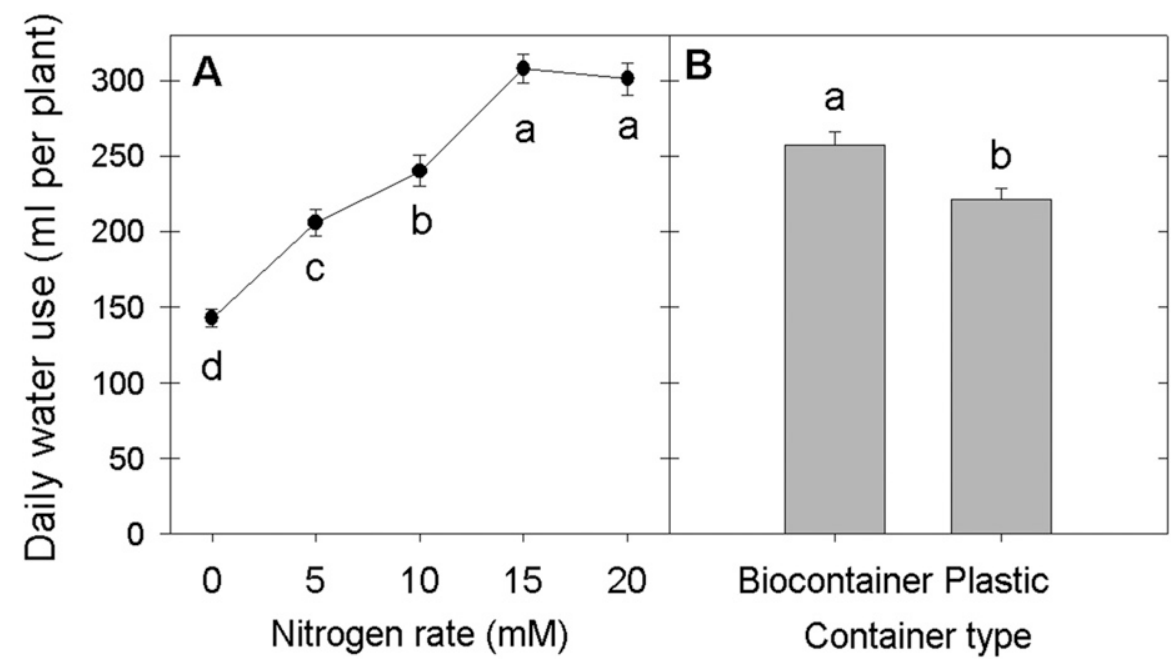

Fig. 5. Daily water use of Hydrangea macrophylla 'Merritt's Supreme' affected by $\mathrm{N}$ rate (A) or container type (B). Hydrangea plants were fertilized with $0,5,10,15$, or $20 \mathrm{~mm} \mathrm{~N}$ from $\mathrm{NH}_{4} \mathrm{NO}_{3}$, grown in plastic container or paper biocontainer, and irrigated once or twice per day with the same total daily irrigation volume. Daily water use was measured using a gravimetric method by subtracting pot weight $24 \mathrm{~h}$ after irrigation from pot weight at container capacity using plants irrigated once per day. Different lowercase letters in a figure suggest significant difference among $\mathrm{N}$ rate or between container types compared by Fisher's least significant difference test at $P<0.05$. the highest $\mathrm{N}$ concentrations in leaf, root, and the plant average (Fig. 9). Stem N concentration was unaffected by $\mathrm{N}$ rate. One irrigation per day increased stem $\mathrm{N}$ concentration by $6.4 \%$ compared with two irrigations per day. Plastic containers resulted in $10.3 \%$ and $9.6 \%$ higher root and average plant $\mathrm{N}$ concentrations than biocontainers, respectively.

\section{Discussion}

Hydrangeas are generally considered to have high nutrient requirements, especially $\mathrm{N}$, to support their vigorous growth (Bi and Scagel, 2008; Bi et al., 2008). Greater N rate increased plant biomass, leaf quality, tissue $\mathrm{N}$ content, and flower number and size in 'Merritt's Supreme' hydrangea (Bi et al., 2008), which is consistent with our results, in which higher $\mathrm{N}$ rates produced plants with greater PGI, leaf area, dry weights, and tissue $\mathrm{N}$ concentrations. Similar results between N rate and growth are also reported for azalea (Rhododendron sp.) and 'Bartlett' pear (Pyrus communis) (Bi et al., 2007; Cheng et al., 2001). High tissue $\mathrm{N}$ content in late 
summer or fall is considered beneficial for spring growth and flowering the following season that is supported by the remobilization of stored N (Bi et al., 2003; Cheng and Xia, 2004; Millard, 1995). On the other hand, runoff of $\mathrm{N}$ to the environment due to overapplication of fertilizer can cause potential contamination of groundwater and should be avoided. According to our results, $20 \mathrm{~mm} \mathrm{~N}$ resulted in the greatest plant DW, leaf SPAD reading, leaf area, and tissue $\mathrm{N}$ concentration (in leaf, root, and average plant). Plant growth index, root length, and surface area were comparable with 15 and $20 \mathrm{~mm} \mathrm{~N}$ in plastic or in biocontainers. These results suggest that the optimal $\mathrm{N}$ rate for 'Merritt's Supreme' may be greater than the highest rate used in our study, but will depend on the variables used to assess plant quality. Because our study was focused on vegetative growth period, decisions on the optimum $\mathrm{N}$ rate should include flowering performance in the

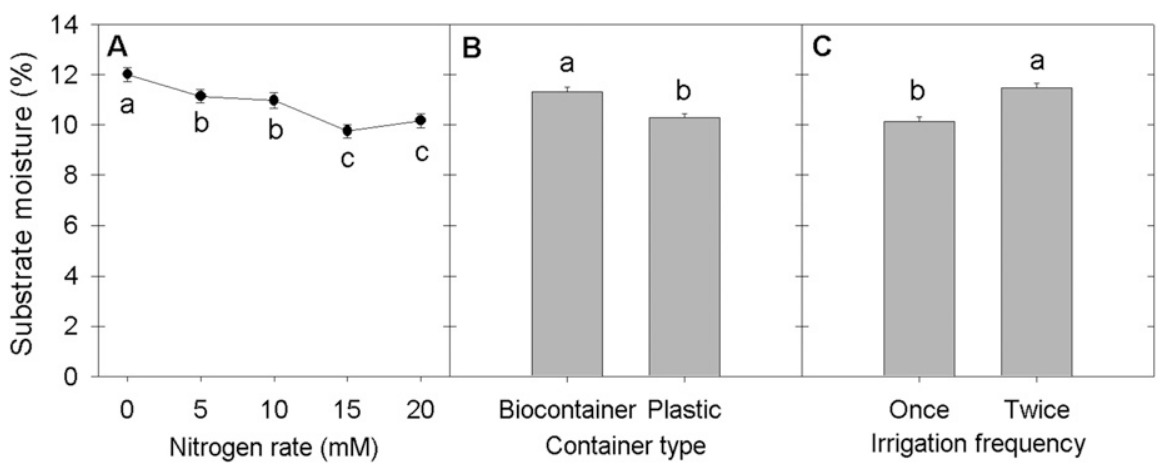

Fig. 6. Substrate moisture of Hydrangea macrophylla 'Merritt's Supreme' affected by N rate (A), container type (B), or irrigation frequency $(\mathbf{C})$. Hydrangea plants were fertilized with $0,5,10,15$, or $20 \mathrm{~mm} \mathrm{~N}$ from $\mathrm{NH}_{4} \mathrm{NO}_{3}$, grown in plastic container or paper biocontainer, and irrigated once or twice per day with the same total daily irrigation volume. Substrate moisture was measured at $5-\mathrm{cm}$ depth using a soil moisture sensor. Different lowercase letters in a figure suggest significant difference compared by Fisher's least significant difference test at $P<0.05$.

following season and whether nursery growers are marketing flowering plants or not.

In this study, more frequent irrigation increased substrate moisture but had little influence on plant growth or nutrient uptake. Scagel et al. (2012) reported that the effect of irrigation frequency on nutrient uptake in rhododendron (Rhododendron sp.) may be a result of effect on plant biomass, rather than a result of substrate nutrient availability or plant uptake ability. The accumulation of $\mathrm{N}$ in plant tissue is regulated by the growth rate and rate of biomass accumulation of a given species, especially under sufficient $\mathrm{N}$ supply (Gastal and Lemaire, 2002). In our study, two irrigations per day were designed to decrease leaching of nutrients to the environment and alleviate possible plant water stress during hot summer conditions by maintaining a higher substrate moisture level. Although two irrigations per day increased substrate moisture at $5-\mathrm{cm}$ depth, $g_{\mathrm{S}}$, an indicator of plant water status, was unaffected by irrigation frequency, suggesting increased substrate moisture with two irrigations per day may not have improved water status (or reduced water stress) of hydrangea plants.

Substrate moisture at 5-cm depth generally decreased with increasing $\mathrm{N}$ rate, with 15 and $20 \mathrm{~mm} \mathrm{~N}$ resulting in the lowest moisture. Plant water uptake through the root is mainly
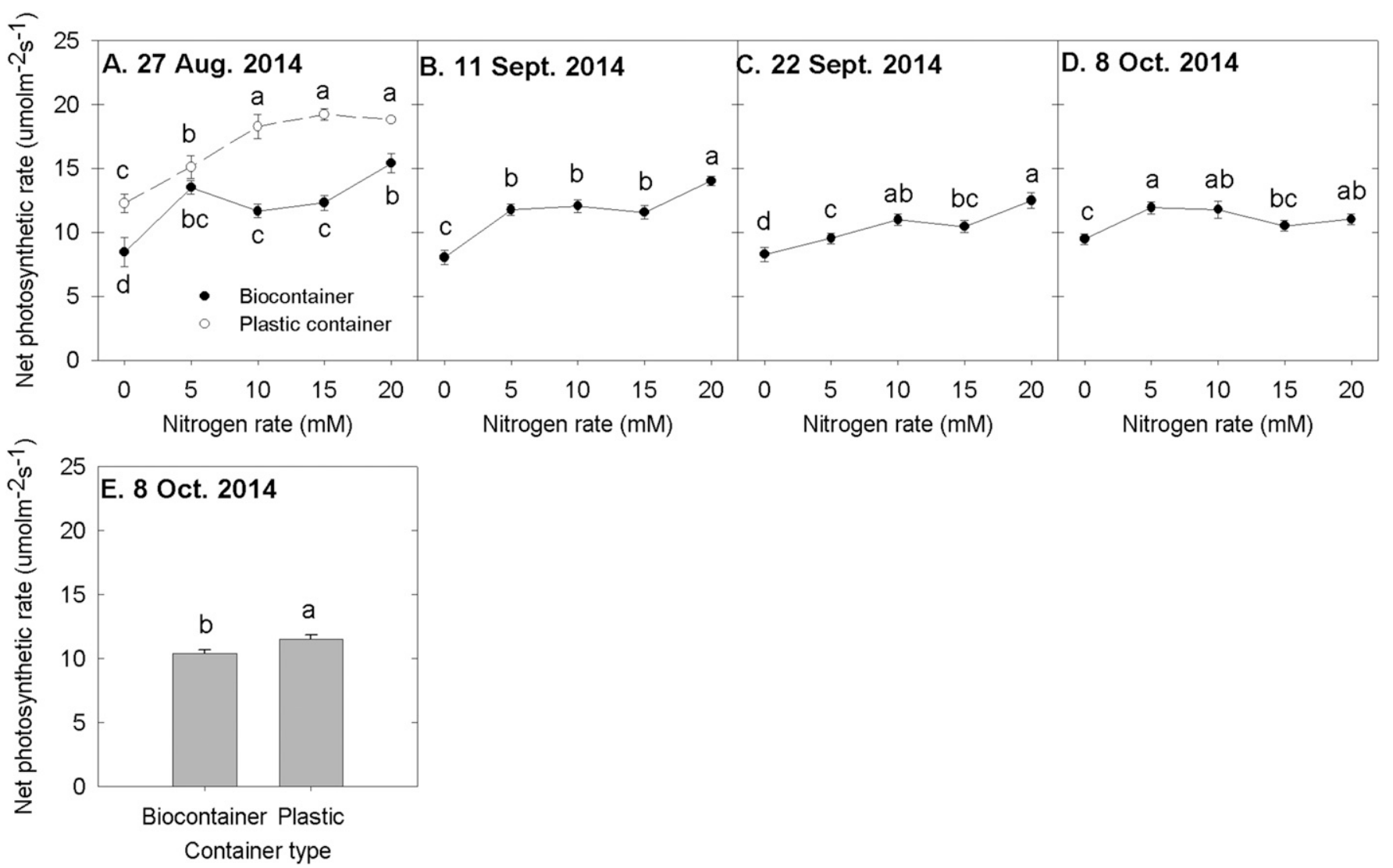

Fig. 7. Net photosynthetic rate of Hydrangea macrophylla 'Merritt's Supreme' affected by the interaction between N rate and container type on 27 Aug. (A), by the main effect of $\mathrm{N}$ rate on 11 Sept. (B) and 22 Sept. (C), or by the main effects of $\mathrm{N}$ rate (D) and container type (E) on 8 Oct. with no interactions between main effects. Hydrangea plants were fertilized with $0,5,10,15$, or $20 \mathrm{~mm} \mathrm{~N}$ from $\mathrm{NH}_{4} \mathrm{NO}_{3}$, grown in plastic container or paper biocontainer, and irrigated once or twice per day with the same total daily irrigation volume. Different lowercase letters in a figure suggest significant difference among all treatment combinations compared by Fisher's least significant difference test at $P<0.05$. 


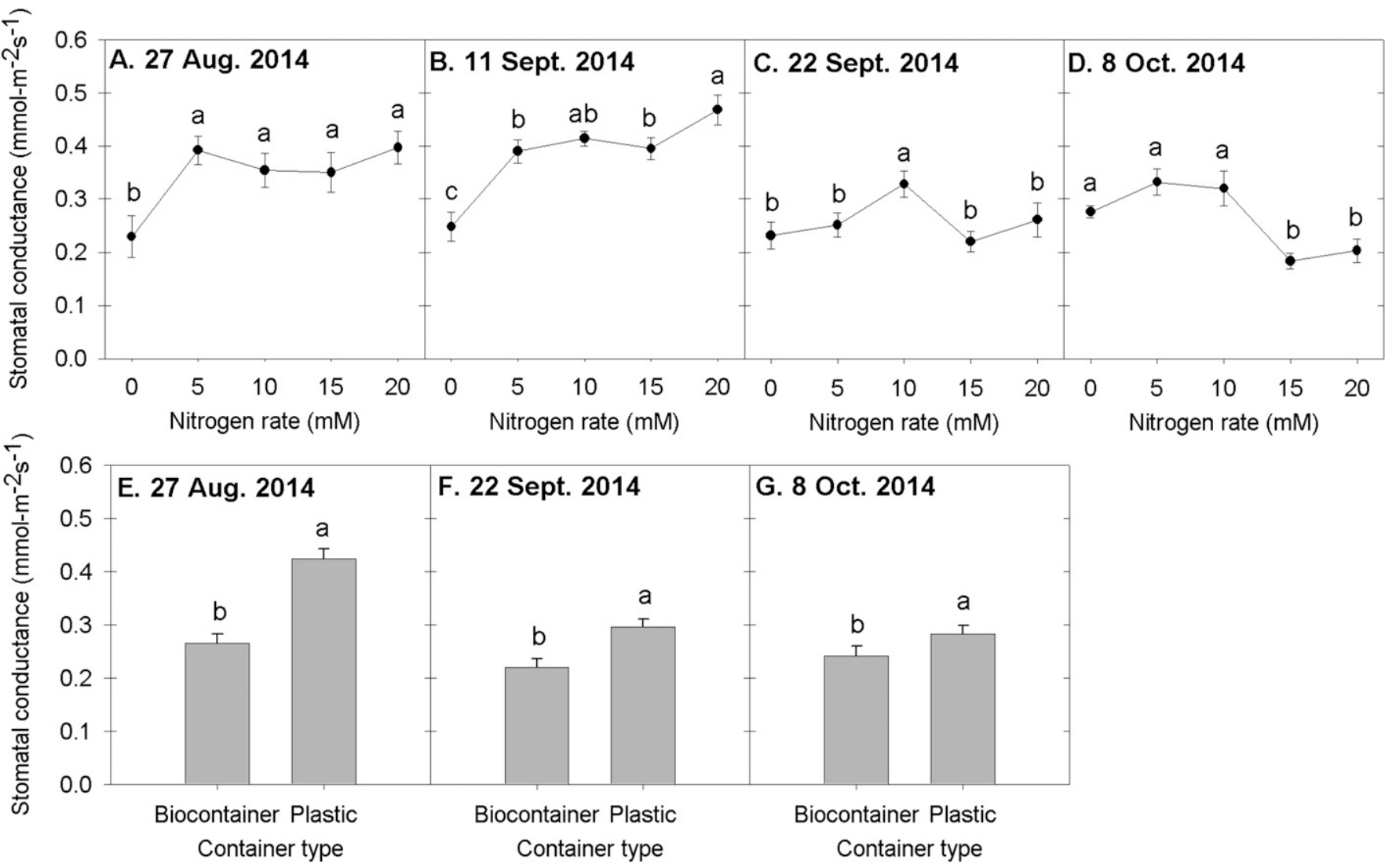

Fig. 8. The stomatal conductance $\left(g_{\mathrm{S}}\right)$ of Hydrangea macrophylla 'Merritt's Supreme' affected by N rate (A-D), or by container type (E-G) on different measurement dates. Hydrangea plants were fertilized with $0,5,10,15$, or $20 \mathrm{~mm} \mathrm{~N}$ from $\mathrm{NH}_{4} \mathrm{NO}_{3}$, grown in plastic container or paper biocontainer, and irrigated once or twice per day with the same total daily irrigation volume. Irrigation frequency did not affect $g_{\mathrm{s}}$. Different lowercase letters in a figure suggest significant difference among $\mathrm{N}$ rates or between container types compared by Fisher's least significant difference test at $P<0.05$.
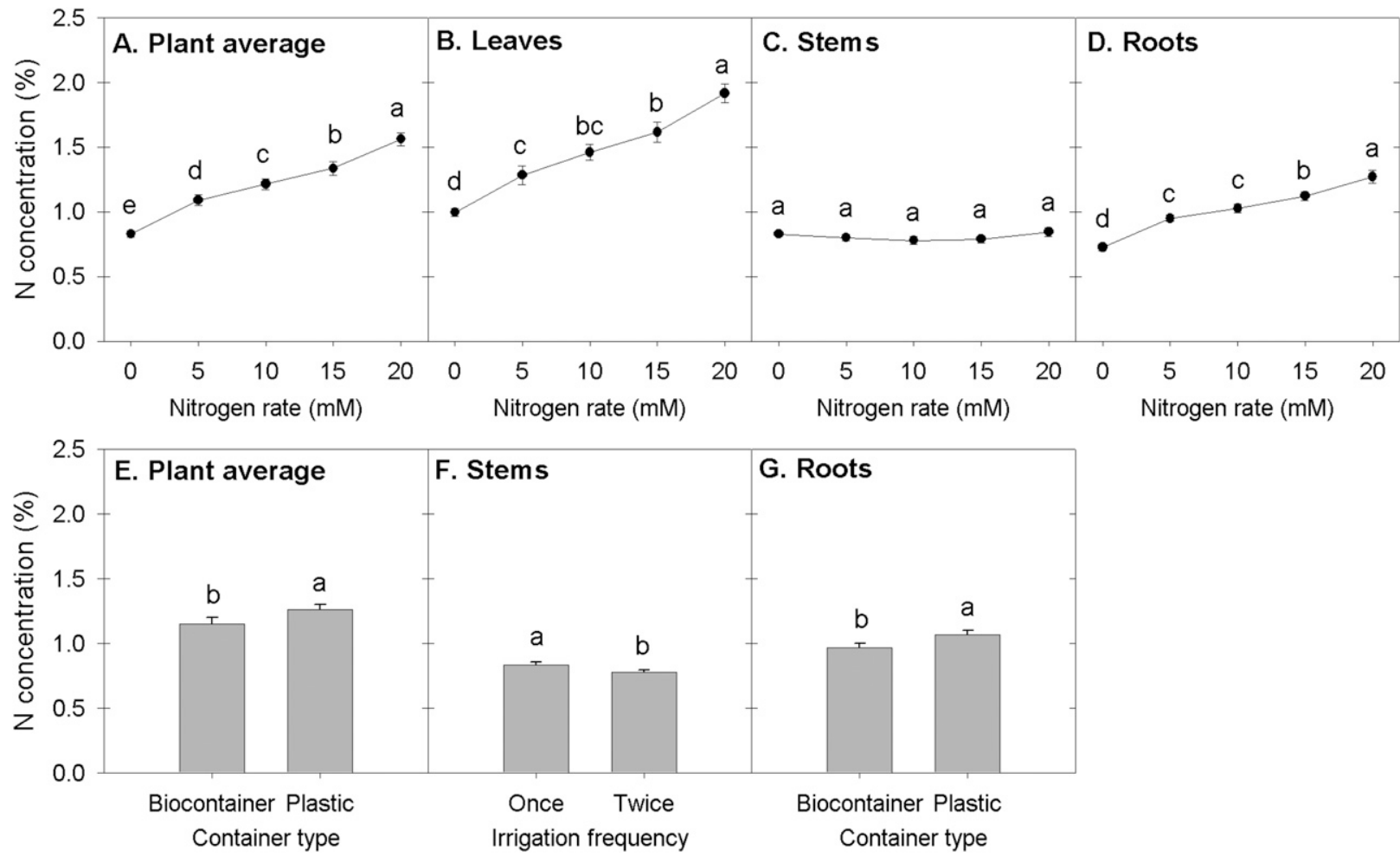

Fig. 9. Tissue $\mathrm{N}$ concentration of Hydrangea macrophylla 'Merritt's Supreme' affected by $\mathrm{N}$ rate in the plant, leaves, and roots (A-D), by container type in the plant (E) and roots $(\mathbf{G})$, or by irrigation frequency in stems $(\mathbf{F})$. Hydrangea plants were fertilized with 0, 5, 10, 15, or $20 \mathrm{~mm} \mathrm{~N}$ from $\mathrm{NH}_{4} \mathrm{NO}_{3}$, grown in plastic container or paper biocontainer, and irrigated once or twice per day with the same total daily irrigation volume. Different lowercase letters in a figure suggest significant difference among $\mathrm{N}$ rates, between container types, or between irrigation frequencies compared by Fisher's least significant difference test at $P<0.05$. 
lost through transpiration and evaporation (Jason and Lawlor, 1979; McElrone et al., 2013). Hydrangea plants fertilized with 15 and $20 \mathrm{~mm} \mathrm{~N}$ had higher PGI and possibly transpire more water than plants fertilized with $\mathrm{N}$ rates of 0 to $10 \mathrm{~mm} \mathrm{~N}$. Therefore, lower substrate moisture with 15 and $20 \mathrm{~mm}$ $\mathrm{N}$ was consistent with high transpiration and water use of these plants. Two irrigations per day increased substrate moisture. With one irrigation per day, lower moisture at 15 and $20 \mathrm{~mm} \mathrm{~N}$ did not limit plant root growth, possibly because plants were established to have a robust root system. Two irrigations per day increased root length at $10 \mathrm{~mm} \mathrm{~N} \mathrm{com-}$ pared with one irrigation. It is possible that increased moisture level promoted plant root growth when it was not as established as at 15 or $20 \mathrm{~mm} \mathrm{~N}$, considering that 15 and $20 \mathrm{~mm} \mathrm{~N}$ resulted in higher root DW than $10 \mathrm{~mm}$ N. However, altered substrate moisture did not affect $\mathrm{N}$ uptake measured by tissue $\mathrm{N}$ concentration, except for increased stem $\mathrm{N}$ concentration with two irrigations per day.

The paper biocontainer used in this study increased DWU of hydrangea plants compared with plastic containers. Wang et al. (2015) also reported increased DWU in plants grown in wood pulp containers compared with plastic containers. The wood pulp container used by Wang et al. (2015) is made from similar materials and manufactured by the same company as the paper biocontainers used in our study. However, substrate moisture at $5-\mathrm{cm}$ depth was higher in biocontainers than in plastic containers. In a traditional plastic container, evaporation is mainly through the substrate surface. Evaporation occurred through both substrate surface and container sidewalls in the paper biocontainers. This characteristic may have contributed to increased DWU besides plant transpiration. Higher substrate moisture at 5$\mathrm{cm}$ depth in biocontainers also may result from the considerable evaporation through the container sidewall, leaving high moisture level toward the substrate surface. By comparison, moisture is mainly lost through the substrate surface in plastic containers, which resulted in the lower moisture at 5-cm depth. Therefore, the different evaporation patterns in the two container types may have caused the higher substrate moisture at 5-cm depth in paper biocontainers than plastic containers. Nambuthiri et al. (2015) found lower substrate temperature and lower sidewall temperature in a wood pulp alternative container than in black plastic containers. The contribution of sidewall water loss to overall container evapotranspiration has a major influence on reducing substrate temperature and the evaporative cooling effect, associated with increased water use, and may help reduce heat stress and enhance plant survival in locations with high summer temperatures (Nambuthiri et al., 2015). When grown in an ebb-and-flood subirrigation system, 'Rainier Purple' cyclamen (Cyclamen persicum) had higher dry root weights when grown in paper and wood fiber containers than in plastic containers (Beeks and Evans, 2013). Beneficial effects on root growth were also found on 'Chiffon' Encore ${ }^{\circledR}$ azalea when grown in paper biocontainers compared with black plastic containers (Li et al., 2018). In the current study, container type had little influence on plant growth. Even though biocontainers had greater substrate moisture at $5 \mathrm{~cm}$ than plastic containers, biocontainers resulted a higher DWU and lower $\mathrm{N}$ uptake. These results indicate that although both container types produce similar plants after 3 months, using biocontainers will require a greater amount of water and may have a higher potential for nutrient leaching from the substrate.

The paper biocontainer resulted in lower $g_{\mathrm{S}}$ and lower net photosynthetic rate than in plastic containers, indicating that the increased water use in biocontainers caused greater water stress and decreased opening of stomata in hydrangea plants. Rose et al. (1999) reported plant growth of some woody ornamentals, such as crabapple (Malus $\times$ zumi) and maple (Acer $\times$ freemanii E.), were enhanced more by minimizing water stress than by increasing fertilizer concentration. Biocontainer-produced hydrangea plants were of comparable visual quality as plastic container-produced plants, but had decreased $\mathrm{N}$ concentration in the root and in the plant on average. With 'Chiffon' Encore $^{\circledR}$ azalea, plants in paper biocontainers had increased PGI, plant dry weight, and plant $\mathrm{N}$ content at 10,15 , or $20 \mathrm{~mm} \mathrm{~N}$ rates, possibly due to azalea's preference for good drainage and aeration, which is provided by the paper biocontainers ( $\mathrm{Li}$ et al., 2018). However, biocontainers decreased $\mathrm{N}$ uptake in hydrangea plants in our study. It is possible the increased water stress in biocontainers limited $\mathrm{N}$ availability or the root's ability to uptake N. Leaf SPAD has been used to help predict leaf $\mathrm{N}$ status in a number of species (Heerema et al., 2014; Jifon et al., 2005; Kim et al., 2013; Netto et al., 2005). Lower leaf SPAD readings in hydrangea plants grown in biocontainers may be a reflection of the reduced $\mathrm{N}$ uptake. Irrigation frequency did not affect plant photosynthetic rate, $g_{\mathrm{S}}$, or $\mathrm{N}$ uptake in the entire plant. Although two irrigations per day resulted in higher substrate moisture than one irrigation per day, such effect did not reduce the water stress caused by biocontainers.

Optimal environment for photosynthesis varies among plant species (Salisbury and Ross, 1992). Day temperature affects photosynthesis, where net photosynthetic rate increases with increasing temperature and starts to drop when reaching a critical high temperature (Armitage et al., 1990; Lasseigne et al., 2007). Under fluctuating environmental conditions, photosynthesis of hydrangea plants was affected by container type, $\mathrm{N}$ rate, or the interaction between $\mathrm{N}$ rate and container type rather than by irrigation frequency. Photosynthetic capacity was reported to have a strong correlation with plant $\mathrm{N}$ status, especially in leaves (Evans, 1989). Heerema et al. (2014) showed a decrease in photosynthesis in pecan (Carya illinoinensis) leaves with decreasing leaf $\mathrm{N}$ when $\mathrm{N}$ was remobi- lized from leaves for fruit development. Nitrogen rate in our study affected net photosynthetic rate and $g_{\mathrm{S}}$ of hydrangea plants on all measuring dates. The highest net photosynthetic rate was found at $20 \mathrm{~mm} \mathrm{~N}$ on 11 Sept. and 22 Sept., suggesting sufficient $\mathrm{N}$ fertilization is needed to support photosynthesis in hydrangea plants. Decreased $g_{\mathrm{S}}$ was reported in response to a short-time water stress with 'Better Boy' tomato plants (Lycopersicon esculentum), in which the depressing effect of water stress on $g_{\mathrm{S}}$ was reversed after rewatering (Gu et al., 1996). Growing hydrangea in plastic containers generally increased plant net photosynthetic rate and $g_{\mathrm{S}}$. Lower $g_{\mathrm{S}}$ of plants in paper biocontainers indicated greater water stress. Such container effect is possibly derived from increased DWU in biocontainers and decreased $\mathrm{N}$ uptake by the hydrangea plants. Although the effects of container type on DWU, substrate moisture, and $\mathrm{N}$ uptake did not result in major differences in plant growth after 3 months, these differences might influence future plant growth and quality in hydrangea plants.

In conclusion, 'Merritt's Supreme' hydrangea has a high $\mathrm{N}$ requirement where $20 \mathrm{~mm} \mathrm{~N}$ resulted in the greatest plant dry weight, leaf SPAD readings, leaf area, and $\mathrm{N}$ concentration (in leaf, root, and the entire plant). $\mathrm{N}$ rate of $15 \mathrm{~mm}$ resulted in similar PGI, root length, and surface area, and dry weights of stem and root as $20 \mathrm{~mm} \mathrm{~N}$. The paper biocontainers used in our study increased DWU while reducing plant photosynthetic rate, $g_{\mathrm{S}}, \mathrm{N}$ uptake, and leaf SPAD readings in hydrangea plants compared with plastic containers. Two irrigations per day resulted in greater substrate moisture at 5-cm depth than one irrigation, but increased irrigation frequency did not compensate for the increased water loss from biocontainers because irrigation frequency did not affect net photosynthetic rate or $g_{\mathrm{S}}$. Considering the negative effects of water use and nutrient uptake of plants grown in the paper biocontainers, use of traditional plastic containers is recommended for nursery production of 'Merritt's Supreme' hydrangea.

\section{Literature Cited}

Armitage, A.M., N.G. Seager, I.J. Warrington, D.H. Greer, and J. Reyngoud. 1990. Response of Oxypetalum caeruleum to irradiance, temperature, and photoperiod. J. Amer. Soc. Hort. Sci. 115:910-914.

Beeks, S.A. and M.R. Evans. 2013. Growth of cyclamen in biocontainers on an ebb-and-flood subirrigation system. HortTechnology 23:173176.

Bi, G. and C.F. Scagel. 2008. Nitrogen uptake and mobilization by hydrangea leaves from foliarsprayed urea in fall depend on plant nitrogen status. HortScience 43:2151-2154.

Bi, G., C.F. Scagel, and R.L. Harkess. 2008. Rate of nitrogen fertigation during vegetative growth and spray application of urea in the fall alters growth and flowering of florists' hydrangeas. HortScience 43:472-477.

Bi, G., C.F. Scagel, L. Cheng, S. Dong, and L.H. Fuchigami. 2003. Spring growth of almond nursery trees depends upon both nitrogen 
reserves and spring nitrogen application. J. Hort. Sci. Biotechnol. 78:853-858.

Bi, G., C.F. Scagel, L.H. Fuchigami, and P.R. Regan. 2007. Rate of nitrogen application during the growing season alters the response of container-grown rhododendron and azalea to foliar application of urea in the autumn. J. Hort. Sci. Biotechnol. 82:753-763.

Bremner, J.M. 1965. Total nitrogen, p. 1149-1178. In: C.A. Black (ed.). Methods of soil analysis, Part 2, Agronomy 9. Soil Sci. Soc. Amer., Inc., Madison, WI.

Brumfield, R.G., A.J. DeVincentis, X. Wang, R.T. Fernandez, S. Nambuthiri, R.L. Geneve, A.K. Koeser, G. Bi, T. Li, Y. Sun, G. Niu, D. Cochran, A. Fulcher, and J.R. Stewart. 2015. Economics of utilizing alternative containers in ornamental crop production systems. HortTechnology 25:17-25.

Cheng, L. and G. Xia. 2004. Growth and fruiting of young 'Concord' grapevines in relation to reserve nitrogen and carbohydrates. J. Amer. Soc. Hort. Sci. 129:660-666.

Cheng, L., S. Dong, S. Guak, and L.H. Fuchigami. 2001. Effects of nitrogen fertigation on reserve nitrogen and carbohydrate status and regrowth performance of pear nursery plants. Acta Hort. (564):51-62.

Currey, C.J. and R.G. Lopez. 2015. Biomass accumulation and allocation, photosynthesis, and carbohydrate status of New Guinea impatiens, geraniums, and petunia cuttings are affected by photosynthetic daily light integral during root development. J. Amer. Soc. Hort. Sci. 140:542-549.

Dirr, M.A. 2004. Hydrangeas for American gardens. Timber Press, Portland, OR.

Dirr, M.A. 1998. Manual of woody landscape plants. The identification, ornamental characteristics, culture, propagation and uses. Stipes Publ., Champaign, IL.

Evans, J.R. 1989. Photosynthesis and nitrogen relationship in leaves of $\mathrm{C}_{3}$ plants. Oecologia 78:9-19.

Evans, M.R., M. Tayler, and J. Kuehny. 2010. Physical properties of biocontainer for greenhouse crops production. HortTechnology 20:549-555.

Gastal, F. and G. Lemaire. 2002. N uptake and distribution in crops: An agronomical and ecophysiological perspective. J. Expt. Bot. 53:789-799.

Gu, S., L.H. Fuchigami, S.H. Guak, and C. Shin. 1996. Effects of short-term water stress, hydrophilic polymer amendment, and antitranspirant on stomatal status, transpiration, water loss, and growth in 'Better Boy' tomato plants. J. Amer. Soc. Hort. Sci. 121:831-837.

Heerema, R.J., D. VanLeeuwen, R. St. Hilaire, V.P. Gutschick, and B. Cook. 2014. Leaf photosynthesis in nitrogen-starved 'Western' pecan is lower on fruiting shoots than nonfruiting shoots during kernel fill. J. Amer. Soc. Hort. Sci. 139:267-274.

Jason, M.J. and D.W. Lawlor. 1979. The relationship between transpiration, root water uptake, and leaf water potential. J. Expt. Bot. 30:169181 .

Jifon, J.L., J.P. Syvertsen, and E. Whaley. 2005. Growth environment and leaf anatomy affect nondestructive estimates of chlorophyll and nitrogen in Citrus sp. leaves. J. Amer. Soc. Hort. Sci. 130:152-158.

Kim, S.H., J.H. Jeong, and L.L. Nackley. 2013. Photosynthetic and transpiration responses to light, $\mathrm{CO}_{2}$, temperature, and leaf senescence in garlic: Analysis and modeling. J. Amer. Soc. Hort. Sci. 138:149-156.

Koeser, A., G. Kling, C. Miller, and D. Warnock. 2013. Compatibility of biocontainer in commercial greenhouse crop production. HortTechnology 23:149-156.

Kuehny, J.S., M. Taylor, and M.R. Evans. 2011. Greenhouse and landscape performance of bedding plants in biocontainers. HortTechnology 21:155-161.

Lasseigne, F.T., S.L. Warren, F.A. Blazich, and T.G. Ranney. 2007. Day/night temperature affects growth and photosynthesis of cultivated Salvia taxa. J. Amer. Soc. Hort. Sci. 132:492500 .

Li, T., G. Bi, G. Niu, S.S. Nambuthiri, R.L. Geneve, X. Wang, T. Fernandez, Y. Sun, and X. Zhao. 2015. Feasibility of using biocontainers in a potin-pot system for nursery production of river birch. HortTechnology 25:57-62.

Li, T., G. Bi, R.L. Harkess, G.C. Denny, E.K. Blythe, and X. Zhao. 2018. Nitrogen rate, irrigation frequency, and container type affect plant growth and nutrient uptake of encore azalea 'Chiffon'. HortScience 53:560-566.

McElrone, A.J., B. Choat, G.A. Gambetta, and C.R. Brodersen. 2013. Water uptake and transport in vascular plants. Nature Educ. Knowledge 4(5):6.

Millard, P. 1995. Internal cycling of nitrogen in trees. Acta Hort. 383:3-13.

Nambuthiri, B., R.L. Geneve, Y. Sun, X. Wang, R.T. Fernandez, G. Niu, G. Bi, and A. Fulcher. 2015. Substrate temperature in plastic and alternative nursery containers. HortTechnology 25:50-56.

Netto, A.T., E. Campostrini, J.G. Oliveira, and R.E. Bressan-Smith. 2005. Photosynthetic pigments, nitrogen, chlorophyll $\alpha$ fluorescence and SPAD-502 readings in coffee leaves. Scientia Hort. 104:199-209.

O’Meara, L., M.R. Chappell, and M.W. van Iersel. 2014. Water use of Hydrangea macrophylla and Gardenia jasminoides in response to a gradually drying substrate. HortScience 49:493-498.

Orozco-Obando, W., G.N. Hirsch, and H.Y. Wetzstein. 2005. Genotypic variation in flower induction and development in Hydrangea macrophylla. HortScience 40:1695-1698.

Reed, S.M., K.D. Jones, and T.A. Rinehart. 2008. Production and characterization of intergeneric hybrids between Dichroa febrifuga and $\mathrm{Hy}$ drangea macrophylla. J. Amer. Soc. Hort. Sci. 133:84-91.

Rose, M.A., M. Rose, and H. Wang. 1999. Fertilizer concentration and moisture tension affect growth and foliar N, P, and K contents of two woody ornamental. HortScience 34:246-250.

Salisbury, F. and C.W. Ross. 1992. Plant physiology. 4th ed. Wadsworth Publ. Co., Belmont, CA.

Sanchez, E.E., T.L. Righetti, D. Sugar, and P.B. Lombard. 1991. Recycling of nitrogen in fieldgrown 'Comice' pears. J. Hort. Sci. 66:479486.
Scagel, C.F., G. Bi, L.H. Fuchigami, and R.P. Regan. 2011. Effects of irrigation frequency and nitrogen fertilizer rate on water stress, nitrogen uptake, and plant growth of container-grown rhododendron. HortScience 46:1569-1603.

Scagel, C.F., G. Bi, L.H. Fuchigami, and R.P. Regan. 2012. Irrigation frequency alters nutrient uptake in container-grown Rhododendron plants grown with different rates of nitrogen. HortScience 47:189-197.

Scheiber, S.M., R.C. Beenson, J. Chen, Q. Wang, and B. Pearson. 2008. Evaluation of irrigation frequency and quantity on leaf gas exchange, growth, and nitrate leaching of coleus in a simulated landscape. HortScience 43:881-884.

Silber, A., G. Xu, I. Levkovitch, S. Soriano, A. Bilu, and R. Wallach. 2003. High fertigation frequency: The effects on uptake of nutrients, water, and plant growth. Plant Soil 253:467477.

Sun, Y., G. Bi, G. Niu, and C. Perez. 2015. Foliar application of dikegulac sodium increased branching of 'Merritt's Supreme' bigleaf hydrangea. HortTechnology 25:306-312.

Tagliavini, M., P. Millard, M. Quartieri, and B. Marangoni. 1999. Timing of nitrogen uptake affects winter storage and spring remobilization of nitrogen in nectarine (Prunus persica var. nectarina) trees. Plant Soil 211:149-153.

U.S. Department of Agriculture. 2014. 2012 Census of Agriculture. Census of Horticultural Specialties (2014). U.S. Department of Agriculture, Washington, DC. <http://www.agcensus. usda.gov/Publications/2012/Online_Resources/ Census_of_Horticulture_Specialties/HORTIC.pdf $>$. van Gelderen, C.J. and D.M. van Gelderen. 2004. Encyclopedia of hydrangeas. Timber Press, Portland, OR.

Wang, X., R.T. Fernandez, B.M. Cregg, R. Auras, A. Fulcher, D.R. Cochran, G. Niu, Y. Sun, G. Bi, S. Nambuthiri, and R.L. Geneve. 2015. Multistate evaluation of plant growth and water use in plastic and alternative nursery containers. HortTechnology 25:42-49.

Weinbaum, S.A., I. Klein, F.E. Broadbent, W.C. Micke, and T.T. Muraoka. 1984. Effect of time of nitrogen application and soil texture on the availability of isotopically labeled fertilizer nitrogen to reproductive and vegetative growth of mature almond trees. J. Amer. Soc. Hort. Sci. 109:339-343.

Xu, G., I. Levkovitch, S. Soriano, R. Wallach, and A. Silber. 2004. Integrated effect of irrigation frequency and phosphorus level on lettuce: $\mathrm{P}$ uptake, root growth, and yield. Plant Soil 263:297-309.

Yeager, T.H., R.D. Wright, D. Fare, C.H. Gilliam, J.R. Johnson, T. Bilderback, and R. Zondag. 1993. Six state survey of container nursery nitrate nitrogen runoff. J. Environ. Hort. 11:206-208.

Zhou, T.S. and N. Hara. 1988. Development of shoot in Hydrangea macrophylla. I. Terminal and axillary buds. Bot. Mag. Tokyo 102:193206. 